Article

\title{
Territorial Cohesion as a Policy Narrative: From Economic Competitiveness to 'Smart' Growth and Beyond
}

\author{
Panagiotis Artelaris * and George Mavrommatis \\ Department of Geography, Harokopio University, 17671 Athens, Greece, E-Mails: partelar@hua.gr (P.A.), \\ gmavrommatis@hua.gr (G.M.) \\ * Corresponding author
}

Submitted: 11 June 2020 | Accepted: 31 August 2020 | Published: 3 December 2020

\begin{abstract}
During the last two decades, a lot of ink has been spent in favour of narrative analysis of policy. According to such approaches, policy processes are influenced by narratives that are spread around specific 'issues' and lead to their solutions. Following a similar vein, this article examines territorial cohesion as a policy narrative and how it can be perceived as a narrative constituted by a diverse narrative structure. Territorial cohesion is a dynamic narrative that changes through time. As time goes by and different politico-economic philosophies get more influential, technological changes also bring along different priorities, broader EU narratives change, and territorial cohesion adapts to such changes. Accordingly, within the post-2014 framework (2014-2020), territorial cohesion's (spatialised) social inclusion perspective was subdued to the economic competitiveness sub-narrative in a globalised world. For the new programming period (2021-2027), the European Cohesion Policy will continue to be increasingly linked to the place-based narrative and most of its funding will be directed towards a 'smarter' and 'greener' Europe within a global space of flows and fast technological changes. The aim of a 'smarter' Europe based on digital transformation and smart growth is a new version of the economic competitiveness sub-narrative, while a 'greener' Europe is the new policy meta-imperative ("European Green Deal"). However, it must be considered how the Coronavirus crisis and the measures to fight its economic effects play out on these policy narratives.
\end{abstract}

\section{Keywords}

European cohesion policy; narrative structure; policy narratives; post-2020 framework; territorial cohesion

Issue

This article is part of the issue "Cohesion in the Local Context: Reconciling the Territorial, Economic and Social Dimensions," edited by Anja Jørgensen (Aalborg University, Denmark), Mia Arp Fallov (Aalborg University, Denmark), Rikke Skovgaard Nielsen (Aalborg University, Denmark), Hans Thor Andersen (Aalborg University, Denmark) and Maja de Neergaard (Aalborg University, Denmark).

(C) 2020 by the authors; licensee Cogitatio (Lisbon, Portugal). This article is licensed under a Creative Commons Attribution 4.0 International License (CC BY).

\section{Introduction}

The European Cohesion Policy (ECP) was implemented in 1989 and has gone through five consecutive periods of multiannual programs or funding; it can be understood as the EU Regional Policy. Since its inception, it has gone through a series of transformations concerning strategies, management, control and audit. More recently, it had to adjust to broader European strategies like the "Lisbon Strategy," "Europe 2020 Strategy" (Medeiros, 2017) and the "European Green Deal." In its initial conception, the ECP had the twin aims of economic and social cohesion, but these earlier goes have been supplemented with territorial concerns in the ECP's own 'spatial turn.' According to the Treaty on the Functioning of the EU (2008), it is the ECP's goal the strengthening of economic, social and territorial cohesion by reducing regional differences, with a special emphasis on the least developed regions as well as areas with special territorial characteristics. More concretely, the ECP attempts to ameliorate such differences through the use of the European Regional Development Fund (ERDF), the 
Cohesion Fund and the European Social Fund. For the period 2014-2020, before the revamp of the EU budget because of the Coronavirus pandemic, the ECP had a total budget of 351.8 billion euros.

Territorial cohesion is a shared competence between the European Commission and the various member states. Some writers have argued that territorial cohesion is the goal par excellence of the ECP insofar as equality between EU territories contains the goals of economic and social cohesion (Medeiros, 2017). Nevertheless, according to Dabinett (2011, p. 2), "territorial cohesion is a construct that is not found outside the documents and discourses that constitutes the words of EU spatial planners and spatial policy." Other writers have argued that territorial cohesion is an EU discursive exercise whose meaning is always generated through its linkages to various discursive chains (Servillo, 2010). Subsequently, if territorial cohesion is an EU policy narrative then its semantic field corresponds to the narrative structure it becomes attached to. Accordingly, among the various ways to methodologically approach it is through narrative analysis.

Narrative analysis forms a significant methodology in the social sciences as it is encountered in numerous disciplines from psychology and economics to sociology and education. During the last decades, narrative inquiry had entered into the realm of policy studies, too. Following such lines, a bulk of research has emerged that investigates the role of narratives in policy processes, policy change and policy outcomes (see, for instance, McBeth, Shanahan, Arnel, \& Hathaway, 2007; Roe, 1989; Shanahan, Jones, \& McBeth, 2011). This body of work has been methodologically based on the position about the social constructive nature of policy realities (Shanahan, Jones, McBeth, \& Lane, 2013). Some writers follow a similar approach, but instead of talking about narratives and the social construction of reality, they prefer to talk about policy discourses (Schmidt \& Radaelli, 2004) and discursive narratives (Atkinson, 1999, 2000). More recently, the early qualitative and poststructuralist narrative policy analysis has been followed by a quantitative and structural approach known as the Narrative Policy Framework (NPF; see Jones \& McBeth, 2010; Shanahan et al., 2011). Nevertheless, some voices claim that the NPF can also be used qualitatively. By all accounts, what is significant is that narrative inquiry is either qualitatively or quantitatively becoming important for the analysis of policy. A few decades after Roe's early suggestion that "storytelling is part of policy analysis, policy analysis should be broadened to include systematic ways of analysing such storytelling" (Roe, 1989, p. 253), narrative inquiry has progressively blended with policy analysis.

There is a wide consensus that policy narratives are stories that policymakers, bureaucrats, interested parties etc. construct to create a plot that leads to specific morals and demands certain solutions (Jones \& McBeth, 2010; Mendez, 2013). According to Atkinson (2000), to understand policy formation we have to first comprehend how policy constructs its 'problems' and what becomes defined as a 'problem.' The reason is that by constructing a certain 'problem,' policy brings to the fore a specific solution to it. Following similar lines, this article aims to analyse the policy narrative of territorial cohesion. However, to do so, territorial cohesion has to be analysed in relation to broader EU narratives. In this sense, the ECP and territorial cohesion are viewed as interdependent narratives. More to the point, the ECP becomes conceived as an EU meta-narrative in close relation to other EU narrative strategies, while territorial cohesion is perceived as a policy narrative constituted by a diverse narrative structure (sub-narratives). The main idea is to examine how the 'metamorphosis' of the ECP through the present (2014-2020) and future (2021-2027) multi-annual frameworks affects the narrative structure of territorial cohesion. Methodologically speaking, this article adopts a constructivist perspective by viewing territorial cohesion as a policy narrative in the making (and un-making). The analysis is based on the social constructive nature of policy realities (Shanahan et al., 2013) by approaching territorial cohesion as a particular form of policy storytelling (Roe, 1989). This narrative investigation draws elements from the international bibliography and how it has categorised Territorial Cohesion's diversified narrative structure, but more importantly, from the analysis of relevant EU policy documents, reports etc. referring both to 2014-2020 and post-2020 programming periods.

\section{Constructing Territorial Cohesion as an Open-Ended Policy Concept}

Territorial Cohesion has its roots in the French tradition of regional policy and planning. More particularly, the roles of Jacques Delors (European Commissioner 1985-1995) and Michel Barnier (former EU Regional Commissioner) are also cited as catalytic for the extension of the ECP from strictly economic and social considerations to territorial ones (Holder \& Layard, 2011). Faludi has argued that a spatially-aware cohesion policy is nothing more than "old (French) wine in new bottles" (Faludi, 2004, p. 1349). Allegedly, the roots of territorial cohesion are related to French regional policy (amenagement des territories; see Faludi, 2010, 2015) where a decentralised state along with the regions as partners attempt to reduce regional disparities by promoting the French Republic's principle of egalité in a territorial way.

The publication of the European Spatial Development Perspective (ESDP) is, first and foremost, widely considered as the milestone towards the creation of a unified EU planning philosophy (European Commission, 1999). According to the ESDP, the main problem of EU territory is the concentration of population, activities and economic prosperity in the specific areas of the 'famous' European pentagon-the metropolitan and surrounding areas of London, Paris, Milan, Munich and Hamburg. 
As the main goal is the balanced and sustainable development of the entire EU territory, polycentric development, parity of access to infrastructure/knowledge and the wise management of natural and cultural heritage are deemed as remedies to the ills and evils of established forms of EU spatial concentration.

Interestingly, many of these goals (especially polycentric development and parity of access) would emerge again and again in subsequent efforts to define a European spatial philosophy. In short, the ESDP articulated several aims and goals supposedly able to deal with the problems resulting from the spatial concentration of people, economic activities and prosperity in specific EU territories. Many of these priorities were successfully transplanted into Territorial Cohesion once it became the third pillar of the ECP.

Territorial cohesion is part and parcel of the much broader phenomenon of multilevel governance. More concretely, the multi-level governance theory (Bache \& Flinders, 2004; Marks, Hooghe, \& Blank, 1996) came from research on the ECP to create a general theoretical policy framework to explain the relationships between Brussels, national governments and regional/urban authorities. The multi-level governance thesis was an early recognition that the ECP increased the political role of regional, urban, local players.

One very popular construction of Territorial Cohesion is that of an open-ended policy concept. It has been presented as a 'vague' concept (Atkinson \& Zimmerman, 2016) or a 'fashionable term' with "many layers of meaning" (Mirwaldt, McMaster, \& Bachter, 2009, p. v). Other scholars have argued about the 'elusive' and 'ambiguous' nature of territorial cohesion that makes it very difficult to be translated into an easily understood and measurable concept (Medeiros, 2016). It has been stated that territorial cohesion is a 'contested,' 'multi-dimensional' and 'dynamic' concept that 'lacks clarity' (Dao, Cantoreggi, Plagnat, \& Rousseaux, 2017). It has also been proclaimed that it has an 'amorphous' nature whilst non-consensus exists about its meaning (van Well, 2012). In short, a "strict definition" about its nature appears almost "impossible" (Bohme \& Gloersen, 2011, p. 3).

An interesting take comes from Abrahams (2014) that proclaims that instead of defining it through an 'essentialist' approach it might be more useful to approach it through a 'pragmatic' one. Such an effort entails letting territorial cohesion be "fuzzy" and "adaptable" (Abrahams, 2014). Instead of ontologically asking what territorial cohesion is, it might be more insightful to ask what it does, how it gets translated into different national contexts and what kind of uses different actors come up with. Such a 'pragmatic' use of the concept is also proposed by Faludi (2015), who states that "[policy] concepts are like wax in our hands: We shape them to suit our purposes...so to understand the concept, we must ask: Who has invoked it [and who is still invoking it], when and why?" (Faludi, 2015, pp. 1-2)

Some writers have gone as far as to ask whether territorial cohesion has the same meaning in all EU national contexts or whether different national interpretations may exist in different member states (Mirwaldt et al., 2008). In this sense, the ambiguity of the concept renders it almost a 'bridging' (Mirwaldt et al., 2008) or even a 'political' concept (Medeiros, 2016). Van Well (2012) has stated that territorial cohesion can be thought of as a 'moving target' that each member-state or region can appropriate and selectively construct its meaning to promote their territorial priorities.

\section{Territorial Cohesion: Tree-Like versus Storyline (Narrative) Approaches}

Territorial cohesion has been the subject of numerous efforts to construct its character and meaning. On the one hand, territorial cohesion is considered to be constituted by several different dimensions without any contradiction/competition between them, in fact, they all seem to 'add up' (Abrahams, 2014). This is the idea of the tree-like model of territorial cohesion, where territorial cohesion breaks down into its essential components, each of them successively becoming assigned to a group of relevant indicators (Abrahams, 2014). Following such methodology, several of territorial cohesion's dimensions come to the fore (see Table 1).

Mirwaldt et al. (2008) have argued that territorial cohesion is comprised of the following four dimensions: 1) a form of poly-centricity that can promote economic competitiveness and innovation; 2) balanced development that reduces socioeconomic disparities; 3 ) accessi-

Table 1. Dimensions of territorial cohesion.

\begin{tabular}{ll}
\hline Writers & Dimensions \\
\hline Mirwaldt et al. (2008) & $\begin{array}{l}\text { polycentricity, balanced development, accessibility to services, facilities and knowledge, } \\
\text { networking and the creation of physical and interactive connections } \\
\text { polycentricity, connectivity through infrastructure, equal access to services }\end{array}$ \\
Bohme et al. (2011) & $\begin{array}{l}\text { accessibility, services of general economic interest, territorial capacities/endowments/assets, } \\
\text { city networking, functional regions } \\
\text { Medeiros (2016) }\end{array}$ \\
\hline
\end{tabular}


bility to services, facilities and knowledge irrespectively to where one lives; 4) networking and the creation of physical and interactive connections between centres and other areas (Mirwaldt et al., 2008).

For Medeiros (2016), territorial cohesion is constituted by the following similar but not identical components: 1) socio-economic cohesion that strengthens economic competitiveness while ensures social integration; 2) territorial polycentricity that promotes a more balanced physical network of areas; 3 ) territorial cooperation and governance at different levels; 4) environmental sustainability (Medeiros, 2016).

Additionally, Dabinett (2011) has suggested that the dimensions of territorial cohesion can be summarised as 1) polycentricity, 2) connectivity through infrastructure and 3) equal access to services. At the policy level, the Bohme Report (Bohme, Doucet, Komornicki, Zaucha, \& Swiatek, 2011), by linking the "Europe 2020 Strategy" with the "Territorial Cohesion Agenda 2020" (TCA 2020) proposes the following five dimensions as crucial: 1 ) accessibility; 2 ) services of general economic interest; 3) territorial capacities/endowments/assets; 4) city networking; 5) functional regions.

As this article promulgates, territorial cohesion can also be seen through the storyline or narrative perspective (Abrahams, 2014). This perspective is interesting as it acknowledges that policies can have different or even competing meanings by being articulated through various sub-narratives (see Table 2). Abrahams (2014), by citing Maarten Hajer, brings to the fore the possibility that particular policy narratives, like territorial cohesion, can be communicated through a diverse narrative structure that might contain antagonising sub-narratives that do not necessarily 'add up.' Following such lines, the meaning of territorial cohesion is disputed through competing storylines. Similarly, van Well (2012) defines territorial cohesion as a series of different sub-narratives coming from different communities of actors. As she says, there are the ESDP storylines, the ESPON storylines, the TCA 2020 storylines, and the European Commission's storylines in their Green Paper on Territorial Cohesion: Turning Territorial Diversity into Strength (European Commission, 2008). More importantly, after the publication of the latter, the European Commission proceeded with a narrative exercise that involved various actors at different levels being asked to speak their minds about territorial cohesion concerning meaning, scope, ways of implementation and more. As part of a synthesis report, several policy sub-narratives came out, such as 1) polycentric development, 2) equal access to facilities, services and knowledge, 3) balanced development, 4) regions with specific geographical features and 5) territorial capital (Sarmiento-Mirwaldt, 2013).

Such a narrative approach has also been taken by the ESPON Interco Project (2010-2012), which attempted to capture, through organised workshops with relevant stakeholders, the various non-mutually exclusive territorial cohesion storylines. The project aimed at starting a dialogue between Territorial Cohesion's competing sub-narratives (Dao et al., 2017). Through a participatory approach, the following storylines broke to the fore: 1 ) smart growth in a polycentric Europe; 2 ) inclusive and balanced development with fair access to services; 3) local development conditions and geographic specificities; 4) environmental sustainability; 5) coordination of policies and territorial governance. Furthermore, six territorial objectives were created while a group of indicators was assigned to each objective (Dao et al., 2017). This was a clear analytical effort to silence possible antagonisms between competing sub-stories by flattening out the various narratives into straight-forward territorial objectives.

\section{Territorial Cohesion and the Place-Based Narrative}

The most relevant EU policy document that attempted to construct territorial cohesion was the Green Paper on Territorial Cohesion: Turning Diversity into Strength (European Commission, 2008). It argued that:

Territorial cohesion is about ensuring the harmonious development of all these places and about making sure that their citizens are able to make the most of the inherent features of these territories. As such, it is a means of transforming diversity into an asset that contributes to sustainable development of the entire EU. (European Commission, 2008, p. 3)

More importantly, territorial cohesion became linked with taking advantage of territorial diversity as allegedly "increasingly competitiveness and prosperity depend on the capacity of people and businesses located there to make the best use of all territorial assets" (European Commission, 2008, p. 3). A year after this publication, a report came out that became known as the Barca Report (Barca, 2009). This policy document further strength-

Table 2. Territorial cohesion's storylines.

\begin{tabular}{ll}
\hline Writers & Storylines \\
\hline Sarmiento-Mirwaldt (2013) & $\begin{array}{l}\text { Polycentric development, equal access to facilities, services, knowledge, balanced } \\
\text { development, regions with specific geographical features, territorial capital }\end{array}$ \\
Dao et al. (2017) & $\begin{array}{l}\text { Smart growth, inclusive and balanced development, local development conditions and } \\
\text { geographical specificities, environmental sustainability, coordination of policies and } \\
\text { territorial governance }\end{array}$ \\
\hline
\end{tabular}


ened the link between territorial cohesion and the placebased approach (Mendez, 2013).

The Barca Report brought to the policy front the place-based approach: "A place-based policy is a longterm strategy aimed at tackling persistent underutilization of potential by reducing social exclusion in specific places through external interventions and multi-level governance" (Barca, 2009, p. vii). Furthermore, it was argued that public interventions and economic institutions had to be tailored to local conditions and rely on local knowledge, networks and partnerships. The new policy approach aimed "at giving all places the opportunity to make use of their potential (efficiency) and all people the opportunity to be socially included independently of where they live (social inclusion)" (Barca, 2009, p. xii).

On a theoretical level, many of these ideas come from modern political philosophy. According to Rawls' (1971/1999) Theory of Justice, the principle of fair equality of opportunity in just and democratic societies translates into the dictum that social and economic differences can only be tolerated if they are associated with offices and positions that are open to everyone. Nevertheless, this Rawlsian principle of justice is aspatial, as his theory does not examine the distribution of injustices in space (Malý, 2016); it does not take account of the position of the equality of opportunity in space. The spatialisation of this principle would mean that people should not be disadvantaged because of their location; location should not be a hindrance or constraint to the life-chances of individuals.

Many of these ideas of territorialised social inclusion originate from the European social model that was built upon the social-democratic and Christian-democratic canon of European politics and maintained 'appropriate balance' between the individual, the market and the state (Faludi, 2007). The French principle of egalite increasingly found its spatial correlation through the core political belief that citizens should not experience spatial disadvantage or be deprived of essential services. Decades later, the Barca Report promulgated that an EU “territorialized social agenda" (Barca, 2009, p. 120) should create equality between places as people live their lives and built their human capabilities in specific locales.

In this sense, the life-chances approach of individuals, or the freedom of individuals to live decently according to their potential in their places of residence (very similar to Amartya Sen's (2000) argument about development as freedom in the case of the developing world), becomes part and parcel of territorial cohesion's territorialised social inclusion perspective as location should not be a hindrance. This imperative becomes articulated through the storyline of parity of access or equity to services, facilities, infrastructure and knowledge. It also becomes communicated through the concept of 'general services of economic interest' that cover all fundamental needs of people to lead a decent life (jobs, health, education, security). Through the equal provision of "general services of economic interest" in all places, people are not deprived of public goods because of where they happen to live (Bohme et al. 2011, p. 6).

After the Barca Report, several EU policy publications came out that stressed the importance of the place-based narrative. The EU document Territorial Cohesion: Unleashing the Territorial Potential (European Commission, 2009, p. 8) argued that a local development methodology "is possibly the only effective way to address questions related to social inclusion and the specific challenges facing inhabitants in disadvantaged areas." According to the Cohesion Policy Support for Local Development report, a new emphasis on local development was needed to cope with the aftermath of the 2008 economic crisis (European Commission, 2010, p. 6). The Bohme Report (Bohme et al., 2011) stressed the role of 'territorial keys' in the promotion of territorial cohesion's goals-among them, 'territory-bound' factors like local milieus were cited. According to such narratives, places have the potential for endogenous development, albeit with external help and as part of multi-level governance systems (Servillo, Atkinson, \& Hamdouch, 2016, p. 4). Furthermore, to escape their undeveloped economic structures and their bleak economic futures localities have to take advantage of territorial assets and create new ones (Servillo et al., 2016). Such a placebased narrative takes for granted a bottom-up perspective; local knowledge has to be harnessed while a-spatial theories and policies have to be substituted by placeinformed understandings (Atkinson, 2017).

It has been also suggested that a place-based approach may be more suitable than spatially-blind policies for the economic goals of "Europe 2020 Strategy" to be reached. According to CSIL (2015, p. 3): "A placebased approach is a flexible policy choice which can be more successful in delivering the 2020 Europe strategy than traditional approaches, typically sector-based and top-down." In GSC $(2017$, p. 6) it was stated that:

In order to achieve the desired impact and added value of Cohesion Policy, a 'one size fits all' approach is not optimal; the policy, its delivery mechanisms, legal framework and interpretations need to take account of different social, territorial and economic realities to address the specific situations on the ground.

From all the above, it becomes apparent that the placebased narrative became progressively mainstreamed into the ECP and territorial cohesion policy narratives within the post-2014 framework (2014-2017; Mendez, 2013).

\section{Economic versus Socio-Spatial Sub-Narratives of Territorial Cohesion}

As argued, territorial cohesion as a policy narrative is related to a diverse narrative structure that includes various sub-narratives. Some writers have argued that com- 
petition or antagonism might exist between the different territorial cohesion storylines. By and large, this competition involves its two most significant sub-narratives: economic competitiveness and territorialised social cohesion; the underlying economic and socio-spatial stories of this policy narrative (Atkinson \& Zimmerman, 2016). On the one hand, the economic competitiveness subnarrative becomes articulated by reference to polycentricity, smart growth and connectivity while the sociospatial storyline becomes communicated through the themes of accessibility (equal/fair access) to services and balanced development (see, for instance, Bohme et al., 2011; Dabinett, 2011; Medeiros, 2016; Mirwaldt et al., 2009). From all the above, a couple of questions arise: Is territorial cohesion as a policy narrative mostly about promoting economic competitiveness or reducing sociospatial disparities (territorialised social inclusion), or simply both?

Nevertheless, if we go back to the Green Paper on Territorial Cohesion: Turning Territorial Diversity into Strength (European Commission, 2008) and the Barca Report (Barca, 2009), these two sub-narratives become intertwined as socio-spatial inclusion is merged with economic competitiveness goals. This merging takes place through the concept of territorial capital. More particularly, this notion of different forms of capital originates from the work of Bourdieu and his conceptualisation of capital as economic, symbolic, cultural and social. In this take, capital is extended to include territorial assets. This is the narrative of territorial diversity as strength and the place-based approach together, where territorial capital should be exploited to take advantage of endogenous local strengths and promote the economic and sociospatial aims of territorial cohesion. In other words, territorial capital by taking advantage of local strengths can promote economic competitiveness and territorialised social inclusiveness. Following such lines, territorial capital becomes the new policy instrument for the merging of territorial cohesion's twin sub-narratives in a Europe of spatial specificities (Sarmiento-Mirwaldt, 2013).

However, the narrative conviction of such an argument remains contested. According to some writers, after the signing of the Lisbon Treaty (2009), the two sub-narratives of economic competitiveness and sociospatial inclusiveness became less compatible with each other (Malý, 2016). Others have suggested that the economic competitiveness sub-narrative has dominated over socio-spatial cohesion's considerations (Atkinson \& Zimmerman, 2016; Holder \& Layard, 2011). In this sense, the two significant storylines either do not add up or are even in competition with each other.

\section{Broader Narrative Changes within the Post-2020 Framework}

The ECP within the post-2014 context (2014-2020) has been closely connected with the place-based narrative and has focused more on economic competitiveness rather than redistribution and social cohesion (Avdikos \& Chardas, 2016; Medeiros, 2017). More to the point, it has been argued that the ECP is "re-oriented, away from the traditional goal of promoting balanced socio-economic development, towards a regional growth-policy perspective that puts the issue of competitiveness as a prerequisite for regional convergence" (Avdikos \& Chardas, 2016, p. 97).

Up until now, the ECP has been funded by the ERDF, the Cohesion Fund and the European Social Fund. Furthermore, the ECP within the post-2014 framework has the following thematic priorities: 1 ) research, technological development and innovation; 2) information and communication technologies; 3) small and mediumsized enterprises (SMEs); 4) low carbon economy; 5) climate change; 6) environment and resource efficiency; 7) transport; 8) employment; 9) social inclusion and poverty; 10) education and training; 11) efficient public administration.

More specifically, the ERDF provides financial assistance to all EU regions that are subsequently categorised as less developed, in transition and more developed regions. Although the ERDF finances all 11 thematic objectives, its main focus is on objectives $1-4$, namely, research and innovation, information and communication technologies, SMEs and the low carbon economy. From this perspective, the ERDF has as its main objectives the promotion of economic competitiveness through smart growth and the creation of a green economy.

For the multi-annual period of 2014-2020, developed regions have to direct at least $80 \%$ of ERDF funding at the national level towards two or more of these four objectives, and at least $20 \%$ on environmental priorities. For regions in transition, the proportions of ERDF funding are $60 \%$ and $15 \%$, and for less developed $50 \%$ and $12 \%$ (Widuto, 2018). Additionally, the Cohesion Fund supports infrastructural projects in EU member states with gross national income (GNI) below $90 \%$ of the EU average. The Cohesion Fund focuses on priorities 4-7, namely, low carbon economy, climate change, environment and resource efficiency and transport. With this in mind, it can be argued that the Cohesion Fund has an environmental and transport-related focus, but because it contains a technical assistance component, it contributes to the 11th thematic objective, namely efficient public administration.

After this brief description of the ECP for 2014-2020, it is logical to wonder what kind of changes the post-2020 programming period will bring. Are there any broader changes within the metanarrative of ECP for the next funding period? If the current period has been accompanied by the rise of the place-based narrative and the economic competitiveness storyline (Avdikos \& Chardas, 2016; Medeiros, 2017; Mendez, 2013), what are the narrative priorities of the next to come? These are the questions that will guide the brief analysis that follows.

According to the European Commission's proposal for the next multiannual financial period (2021-2027), 
and before the revamp of the budget because of the Coronavirus pandemic, around 370 billion euros have been assigned to the goals of economic, social and territorial cohesion (European Commission, 2018). The proposal comes with a reduction in funds that will become allocated to ECP. There has been a funding reduction from $34 \%$ to $29 \%$ of the total EU budget. Of course, such negative budgeting developments have created a lot of steer among interested parties and a hashtag has been created, \#CohesionAlliance supporters, backed by several stakeholders and EU leading associations of regions and cities. Discussions have been quite heated around the finalisation of thematic priorities and the allocation of funding to each Member State. According to the proposal, the majority of funding from the ERDF and the Cohesion Fund will be directed towards the twin objectives of a 'smarter' and 'greener' Europe, governed by a single regulation (previously they were covered by two separate regulations). On the other hand, the new European Social Fund for the period 2021-2027 becomes independent and will no longer be part of ECP. It will be named as European Social Fund + and be governed by its own regulation (European Social Fund + Regulation). It will be geared towards implementing the goals of the European Pillar of Social Rights. The European Social Fund + Regulation will merge the former European Social Fund, the Youth Employment Initiative, the Fund for European Aid to the Most Deprived, the Employment and the Social Innovation Programme and the EU Health Programme.

From the 11 thematic priorities of the multiannual framework of 2014-2020, the new financial period (post-2020) has only five: 1) a smarter Europe through innovation, digitisation, economic transformation and support for small and medium-sized businesses; 2) a greener, carbon-free Europe, implementing the Paris Agreement and investing in energy transition, renewables and the fight against climate change; 3) a more connected Europe, with strategic transport and digital networks; 4) a more social Europe, delivering on the European Pillar of Social Rights and supporting quality employment, education, skills, social inclusion and equal access to healthcare; 5) a Europe closer to citizens, by supporting locally-led development strategies.

As argued above, the biggest part of funding from the ERDF and the Cohesion Fund will go towards the first two objectives that allegedly have the "highest added value" (Widuto, 2018). At the same time, the role of the place-based narrative remains strong as a tailored (place-based) approach to regional development is being sought after (Margaras, 2018). There is a strong emphasis on cities, as cities are seen not only as the engines of growth and innovation, but also the spaces of accumulated social, economic and environmental problems. For this reason, it is proposed that $6 \%$ of the European Regional funding should be directed to sustainable urban development, while a new European Urban Initiative will be created.
The European Commission, in order to proceed with the budget restrictions for the new multi-annual period (from $34 \%$ to $29 \%$ of the total EU budget), had three options: 1) make cuts across the board; 2) fund developed regions; or 3) keep selectively supporting key thematic areas and further reduce funding in secondary objectives. By deploying the notion of the highest EU 'added value,' which was based on a series of ex-post evaluations of previous cohesion policy periods, the European Commission eventually decided to follow the third option and further boost a budgeting concentration of the European Regional Fund (with a budget more than five times higher than the Cohesion Fund) on the thematic schemes of a 'smarter' and 'greener' Europe (objectives 1-2).

For countries with a GNI lower than $75 \%$ of the European average, $35 \%$ of the budget has to be spent on 'smart growth' and 30\% on the 'green economy' ( $65 \%$ of the total budget). For countries with a GNI between $75-100 \%$ of the European average, the percentages that have to be spent are $45 \%$ and $30 \%$ respectively (75\% of the total budget), whereas for countries with a GNI (GNI) above the European average, the percentage for both objectives is a minimum $85 \%$ (of the total budget). By comparing the percentages of the ERDF that have to be spent on economic competitiveness and the low carbon economy within the 2014-2020 period with the ones that have to be invested on 'smart' and 'green' Europe within a post-2020 context, it becomes apparent that 'smart' growth and environmental concerns become further strengthened. There seems to be a 'thematic' concentration (Widuto, 2018) of funding in the area of 'smarter' and 'greener' Europe as European Regional Development funding increases from $80 \%$ to $85 \%$ for developed regions, from $60 \%$ to $75 \%$ for regions in transition and $50 \%$ to $65 \%$ for developing regions. Last but not least, the place-based narrative continues to be seen as the most suitable path for the development of EU regions.

As the then European Commissioner for Regional Policy, Corina Cretu, stated, the new multi-annual financial framework has as its main goal "to make Europe smarter and greener" (Cretu, 2018, p. 10; emphasis in original). The intention is to 'modernise' the ECP:

All regions today face the challenge of the digital economy, increasing global competition and economic transformation. This is why we created the new policy objective 'A Smarter Europe-Innovative and Smart Economic Transformation,' which brings together innovation, research and SME support-everything that is needed for regions to thrive and survive in our digital age! We must also not forget that in addition to economic transformation regions must be ready for the transition to the low-carbon economy and circular economy. We brought these two environmental objectives together in the policy objective 'A Greener, Low Carbon Europe.' (Cretu, 2018, p. 10) 


\section{Conclusion: Territorial Cohesion for the New Funding Period (2021-2027) and the Coronavirus Pandemic}

For this article, territorial cohesion is an EU policy narrative constituted by several sub-narratives or a diverse narrative plot. Among others, the narrative structure of territorial cohesion includes the themes of economic competitiveness, territorialised social cohesion, environmental sustainability, etc. However, it is a dynamic narrative that changes over time. As time goes by, and different politico-economic philosophies become more influential, along with technological changes that bring along different priorities, broader EU narratives change and territorial cohesion adapts to such changes as well. More to the point, within the programming period of 2014-2020, territorial cohesion's (spatialised) social inclusion perspective became partly subdued to the economic sub-plot that emphasised economic competitiveness in a globalised world. This narrative change occurred as the ECP had already changed its focus by emphasising growth and employment. For Medeiros (2017), "faced with mounting globalisation processes and neoliberal political agendas, the ECP has gradually shifted its strategic design from the initial goals of achieving socio-economic cohesion to the present [2014-2020] of fermenting growth and jobs" (Medeiros, 2017, p. 1859). Last but not least, both the ECP and territorial cohesion became linked to the place-based narrative to promote locally-led development strategies as 'place' seemed to matter.

For the forthcoming programming period (2021-2027), the ECP will be linked even more strongly to the place-based narrative by increasingly emphasising locally-led development strategies and, by doing so, bringing Europe closer to its citizens. Meanwhile, it will forcefully promote a 'smarter' and 'greener' Europe within a global space of flows and fast technological challenges. Accordingly, territorial cohesion within the post-2020 framework will become more closely linked to economic competitiveness by focusing on 'smart' growth. However, the economic competitiveness subnarrative was already linked to 'smart' growth within the current programming period (2014-2020). Nevertheless, within the forthcoming framework, the narrative link between economic competitiveness, digitisation and economic transformation becomes more paramount through the notion of 'smart' growth. Similarly, environmental sustainability has also been a territorial cohesion's storyline within the current programming period. however, since the adoption of the "European Green Deal," environmental issues have come to the front of ECP and hence they have become transferred to all related policy narratives. As the New Commissioner, Ursula von der Leyen, has argued: "The 'European Green Deal' and digitization will boost jobs and growth, the resilience of our societies and the health of our environment" (European Commission, 2020a). In short, the twin objectives of a 'smart' and 'green' Europe are the new
European policy stories that spread through all policy meta-narratives and narratives and subsequently reach territorial cohesion, too.

And then the Coronavirus pandemic came. As a result, the EU had to reinforce its budget to repair the economic and social damages brought along by the Coronavirus pandemic. The proposed measures include the Next Generation EU initiative with new financing for the 2021-2024 period and a revamped budget for the forthcoming programming period (2021-2027) reaching more than one billion Euros. It is interesting that the pandemic response closely follows the logic of the need for a 'smarter' and 'greener' Europe. As it is argued: "Our generational challenges-the green and digital revolution-are even more important now than before the crisis started. Through the recovery, we will press fast-forward on the twin green and digital revolutions" (European Commission, 2020b). As part of these actions, a new initiative for Recovery Assistance for Cohesion and Territories of Europe (REACT-EU) will provide extra funding of 55 billion euros specifically to cohesion policy. The package includes additional funding that will become available to the ERDF, the European Social Fund and the European Fund for Aid to the Most Deprived. These funds will be provided in 2020 through a revision of the current financial framework (2014-2020) and during 2021-2022 from Next Generation EU. They are additional to the 2014-2020 budget and on top of the forthcoming 2021-2027 budget. REACT-EU will provide financial support to the most important economic sectors for a solid recovery while member states will decide how they will channel them. By all accounts, the focus of the ECP and territorial cohesion for 2021-2027 remains economic competitiveness as smart growth and digital transition and the "European Green Deal" (European Commission, 2020c).

\section{Acknowledgments}

This article was based on research funded by the COHSMO project (2017-2021). This project has received funding from the European Union's Horizon 2020 research and innovation program under grant agreement no. 727058 .

\section{Conflict of Interests}

The authors declare no conflict of interests.

\section{References}

Abrahams, G. (2014). What "is" territorial cohesion? What does it "do"? Essentialist versus pragmatic approaches to using concepts. European Planning Studies, 22(10), 2134-2155.

Atkinson, R. (1999). Discourses of partnership and empowerment in contemporary British urban regeneration. Urban Studies, 36(1), 59-72. 
Atkinson, R. (2000). Narratives of policy: The construction of urban problems and urban policy in the official discourse of British government 1968-1998. Critical Social Policy, 20(2), 211-232.

Atkinson, R. (2017). Policies for small and medium-sized towns: European, national and local approaches, Tijdschrist voor Economiche en Sociale Geographie, 108(4), 472-487.

Atkinson, R., \& Zimmerman, K. (2016). Cohesion policy and cities: An ambivalent relation. In S. Piattoni \& Polverari (Eds.), Handbook on cohesion policy in the EU (pp. 413-428). Cheltenham: Elgar Publishing.

Avdikos, V., \& Chardas, A. (2016). European Union cohesion policy post-2014: More (place-based and conditional) growth, less redistribution and cohesion. Territory, Politics and Governance, 4(1), 97-117.

Bache, I., \& Flinders, M. (2004). Themes and issues in multi-level governance. In I. Bache \& M. Flinders (Eds.), Multi-level governance (pp. 1-11). Oxford: Oxford University Press.

Barca, F. (2009). An agenda for a reformed cohesion policy: A place-based approach to meeting EU challenges and expectations. Brussels: European Commission.

Bohme, K., \& Gloersen, E. (2011). Territorial cohesion storylines: Understanding a policy concept (Brief 1). Luxembourg: Spatial Foresight. Retrieved from https:// www.spatialforesight.eu/files/spatial_theme/ spatial/publications/Brief-2011-1-111025.pdf

Bohme, K., Doucet, P., Komornicki, T., Zaucha, J., \& Swiatek, D. (2011). How to strengthen the territorial dimension of Europe 2020 and the EU cohesion policy. Brussels: European Regional Development Fund.

Consolidated version of the Treaty on the Functioning of the European Union, part three: Union policies and internal actions. Title XVIII: Economic, social and territorial cohesion, Article 174 (2008).

CSIL. (2015). Territorial Agenda 2020 put in practice: Enhancing the effectiveness of Cohesion Policy by a place-based approach. Brussels: Centre for Industrial Studies.

Cretu, C. (2018). Taking up the challenge: To make Europe smarter and greener. Panorama, 2018(65), 10-11.

Dabinett, G. (2011). Promoting territorial cohesion and understandings of spatial justice. Paper presented at the DG Regio's Regional Studies and Slovenia Government Office for Local Self-Government and Regional Policy Conference "What future for cohesion policy? An academic and policy debate," Slovenia.

Dao, H., Cantoreggi, P., \& Rousseaux, V. (2017). Operationalizing a contested concept: Indicators for territorial cohesion. European Planning Studies, 25(4), 638-660.

European Commission. (1999). European spatial development perspective: Towards balanced and sustainable development of the Territory of the EU. Brussels: European Commission

European Commission. (2008). Green paper on territorial cohesion: Turning territorial diversity into strength. Brussels: European Commission.

European Commission. (2009). Territorial cohesion: Unleashing the territorial potential. Brussels: European Commission.

European Commission. (2010). Cohesion policy support for local development: Best practice and future policy options. Brussels: European Commission.

European Commission. (2018). Regulation of the European Parliament and the Council on the European Regional Development Fund and on the Cohesion Fund. Strasburg: European Commission.

European Commission. (2020a). The EU budget powering the recovery plan for Europe. Brussels: European Commission.

European Commission. (2020b). Europe's moment: Repair and prepare for the next generation. Brussels: European Commission.

European Commission. (2020c). EU budget for recovery: Questions and answers on REACT-EU, cohesion policy post-2020 and the European Social Fund+. Brussels: European Commission.

Faludi, A. (2004). Territorial cohesion: Old (French) wine in new bottles? Urban Studies, 41(7), 1349-1365.

Faludi, A. (2007). From European spatial planning to territorial cohesion policy. Regional Studies, 40(6), 667-678.

Faludi, A. (2010). The process architecture of territorial cohesion policy. European Journal of Spatial Planning, 39, 3-18.

Faludi, A. (2015). Territorial cohesion under the looking glass. Brussels: EU Publications. Retrieved from www.ec.europe.eu/regional_policy/archive/ consultation/terco/pdf/lookingglass.pdf

GSC. (2017). Draft Council conclusions: Making cohesion policy more effective, relevant and visible to our citizens (Draft 7896/17). Brussels: GSC.

Holder, J., \& Layard, A. (2011). Drawing out the elements of territorial cohesion: Re-scaling EU spatial governance. Yearbook of European Law, 30(1), 358-380.

Jones, M. K., \& McBeth, M. K. (2010). A narrative policy framework? Clear enough to be wrong? The Policy Studies Journal, 38(2), 329-353.

Malý, J. (2016). Questioning territorial cohesion: (Un)equal access to services of general interest. Papers in Regional Science, 97(2), 323-343.

Margaras, V. (2018). Common provisions regulation: New rules for cohesion policy for 2021-2027. Brussels: European Parliamentary Research Service.

Marks, G., Hooghe, L., \& Blank, K. (1996). European integration from the 1980s: State-centric v. multilevel governance. Journal of Common Market Studies, 34(3), 341-378.

McBeth, M. K., Shanahan, E. A., Arnel, R. J., \& Hathaway, P. L. (2007). The intersection of narrative policy analysis and policy change theory. The Policy Studies Journal, 35(1), 87-108.

Medeiros, E. (2016). Territorial cohesion: An EU concept. 
European Journal of Spatial Development, 60. Retrieved from http://www.nordregio.se/Global/EJSD/ Refereedarticles/refereed60.pdf

Medeiros, E. (2017). From smart growth to European spatial planning: A new paradigm for EU cohesion policy post-2020. European Planning Studies, 25(10), 1856-1875.

Mendez, C. (2013). The post-2013 reform of EU cohesion policy and the place-based narrative. Journal of European Public Policy, 20(5), 639-659.

Mirwaldt, K., McMaster, I., \& Bachter, J. (2009). Reconsidering cohesion policy: The contested debate on territorial cohesion (European Policy Research Paper No. 66). Glasgow: University of Strathclyde.

Rawls, J. (1999). A theory of justice. Cambridge, MA: Belknap Press. (Original work published 1971)

Roe, E. M. (1989). Narrative analysis for the policy analyst: A case study of the 1980-1982 Medfly controversy in California. Journal of Policy Analysis and Management, 8(2), 251-273.

Sarmiento-Mirwaldt, K. (2013). Can multiple streams predict the territorial cohesion debate in the EU? European Urban and Regional Studies, 22(4), 431-445.

Schmidt, V. A., \& Radaelli, C. M. (2004). Policy change and discourse in Europe: Conceptual and methodological issues. West European Politics, 27(2), 183-210.

Sen, A. (2000). Development as freedom. New York, NY: Anchor Books.

Servillo, L. (2010). Territorial cohesion discourses: Hegemonic strategic concepts in European spatial planning. Planning Theory and Practice, 11(3), 397-416.

Servillo, L., Atkinson, R., \& Hamdouch, A. (2016). Small and medium-sized towns in Europe: Conceptual, methodological and policy issues. Tijdschrist voor Economiche en Sociale Geographie, 108(4), 365-379.

Shanahan, E. A., Jones, M. D., \& McBeth, M. K. (2011). Policy narratives and policy processes. The Policy Studies Journal, 39(3), 535-561.

Shanahan, E. A., Jones, M. D., McBeth, M. K., \& Lane, R. R. (2013). An angel on the wind: How heroic policy narratives shape policy realities. The Policy Studies Journal, 41(3), 453-483.

van Well, L. (2012). Conceptualizing the logics of territorial cohesion. European Planning Studies, 20(9), 1549-1567.

Widuto, A. (2018). European Regional Development Fund and Cohesion Fund 2021-2027. Brussels: European Parliamentary Research Service.

\section{About the Authors}

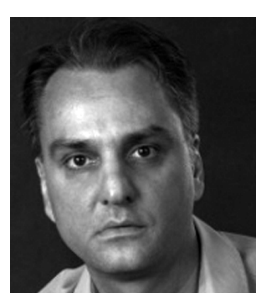

Panagiotis Artelaris is an Assistant Professor of Spatial Economic Analysis at the Department of Geography, Harokopio University. His main research and publication interests are in the areas of spatial economics and economic geography, economic growth and decline, spatial inequalities, and spatial econometrics. https://orcid.org/0000-0002-1921-1751

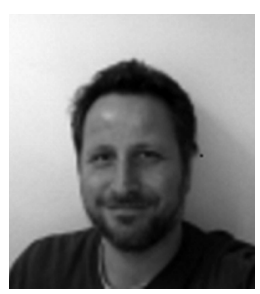

George Mavrommatis is an Assistant Professor at the Department of Geography, Harokopio University. His research interests are in the areas of migration, spatial analysis, transnationalism, citizenship, global politics, etc. He has published considerably in international peer-reviewed journals. 